PRESENTACIÓN DE LIBRO:

\section{La naturaleza ama ocultarse. El cine chileno de Raúl Ruiz (1962 - 1975) de Sergio Navarro}

\section{CATALINA DONOSO PINO}

\author{
> Universidad de Chile. catalina.donoso@uchile.cl \\ Universidad de Valparaíso \\ Facultad de Arquitectura \\ Revista Márgenes \\ Espacio Arte Sociedad \\ La naturaleza ama ocultarse. El cine chileno de Raúl Ruiz \\ (1962 - 1975) de Sergio Navarro \\ Agosto Diciembre 2020 \\ Páginas 35 a 36 \\ ISSN elec. 0719-4463 \\ ISSN imp. 0718-4034 \\ Recepción: abril 2019 \\ Aceptación: octubre 2019
}

Cuando hago clases y hablamos de la obra (teórica o artística) de alguien muerto suelo comentar con mis estudiantes que me cuesta designar muerto a quien ha dejado tras de sí un legado importante. Da la impresión de que quien crea algo que nos moviliza o nos transforma, no muriera nunca. Eso también ocurre con Ruiz, pero de una manera particular. De un modo rotundo su fantasma se las ha arreglado para seguir estrenando películas aún después de muerto, y eso es algo que no se puede decir de cualquier artista por grande que sea su obra. Más particular aún si reconocemos que en su producción fílmica hay un interés por las apariciones, los espectros y los dobles. Recuerdo que el día que murió Ruiz, Valeria de los Ríos, una de nuestras mayores expertas en Ruiz, tenía una invitada argentina que venía a dar una charla a la USACH. Esa noche fuimos en grupo a comer con ella al Parrón, que todavía no cerraba sus puertas para siempre, y no sé si fue ella misma $u$ otro de los comensales quién preguntó que a qué hora llegaba Ruiz. Era por supuesto una broma, pero en este caso podía perfectamente tratarse de una aparición fantasmal probable y todos nos reímos al mismo tiempo que mirábamos disimuladamente alrededor por si esa aparición tenía lugar.

A estas publicaciones fílmicas y literarias post mortem (más que póstumas) -también publicó una novela el 2011- se le agregan la serie de movimientos en torno a su obra que no cesan de ocurrir, restrospectivas y restauraciones de películas, textos críticos y los esperados diarios (dos tomos de un total de más de 1200 páginas publicados en 2017 por Ediciones UDP).

En la introducción a su libro Metamorfosis. Aproximaciones al cine y la poética de Raúl Ruiz (publicado en enero de este año), Valeria de los Ríos escribe: Pareciera que la práctica de lanzar películas hacia el futuro fuera una singular costumbre en Ruiz. El director pareciera estar enviando obras como cartas hacia el futuro, cartas que arriban tardíamente a su destino, llegando a un tiempo y lugar que no había sido previsto. Por qué no pensar entonces todos estos proyectos como respuestas a esas cartas, las que ya han arribado y las por venir.
En el caso de La naturaleza ama ocultarse (sugerente título que dialoga con el cine de indagación ruiziano) esa conversación es con un tiempo y un lugar particular, el periodo chileno de Ruiz, antes del golpe y del exilio, aunque una pequeña parte de la producción analizada alcanza a cubrir esos primeros años de dictadura y destierro, como si ninguna época pudiera pensarse sin leer también sus ecos en el tiempo inmediato que la circunda. Esta carta de respuesta es una conversación que se establece no sólo con las películas, sino que a partir de ellas y alrededor de ellas convoca otros imaginarios e interroga otras dimensiones de lo social y lo cultural para darles contexto y densidad. Sólo por poner un ejemplo y porque me parece notable la relación que convoca, el primer capítulo "Emergencia artístico-cultural" finaliza vinculando el cine de indagación de Ruiz con la sabiduría que Violeta Parra alcanza por su estudio e impregnación de la cultura popular, específicamente entendiendo la tristeza no como contraria a la alegría sino como "dos caras de la única vida que son las dos almas de Chile" (43). Así, estas respuestas terminan conversando tal vez ya no con Ruiz, sino que con otros posibles destinatarios que a su vez conversarán con alguien más, como iniciando conversaciones que se abren al infinito (y tal vez Ruiz o su fantasma terminó respondiendo también a alguna de ellas).

El libro conversa entonces con 13 películas de Ruiz, y a través de ellas con sus posibles ecos en el denso tejido de la cultura. Los límites temporales de estas películas están consignados dentro del marco de los años 1962 y 1975, pero algunas de ellas son ejemplos de estos mensajes lanzados al futuro, como El tango del viudo (1967) su primer largometraje, que se encontraba desaparecido y fue encontrado durante el trabajo de investigación para terminar otra de sus películas inconclusas (La telenovela errante). El tango del viudo no había tenido presupuesto para el audio, y muy pronto podrá exhibirse gracias al trabajo de posproducción de Valeria Sarmiento, su viuda y colaboradora, también cineasta, más de cincuenta años después de su realización. Un ejemplo similar es el de La maleta (1962/2010), el cortometraje que fue su primera obra y que se consideraba no terminada además de perdida hasta 2007, en que se encontró el material sin montar y pudo por fin exhibirse. 0 el caso de Tres tristes tigres que hace casi exactamente 3 años (el 5 de julio de 2016) pudo estrenarse en Chile con su versión restaurada a partir de una copia encontrada por Valeria en el Instituto Fílmico Británico.

La conversación es entonces una que entra y sale de las películas, que las rodea, examina sus bordes y desbordes, pero no deja por eso de explorar sus procedimientos. Sergio Navarro organiza en 6 capítulos esta larga respuesta a las cartas chilenas lanzadas por Ruiz a un elusivo presente y a los posibles futuros, cada uno de ellos haciéndose cargo de distintas obras y sus resonancias. Es destacable que este ordenamiento no sea necesariamente cronológico, sino que se establece en torno a las propias ideas elaboradas por Ruiz en torno a su cine, donde la noción de cine de indagación es una de las ideas matrices para comprender, representar y crear una mirada sobre Chile que huyera de los estereotipos y funcionara como reconocimiento. Así también las tradiciones tomadas de la cultura popular como la del mundo al revés o el cuerpo repartido funcionan como tópicos clave para desarrollar lo que Navarro llama cine del proceso.

Escoger este periodo para responder a sus señales implica enfocarse en la intención ruiziana de encontrarse con las imágenes posibles de Chile, en un proyecto que retoma décadas después. 
Escribe Navarro al final de su libro: Decidió, entonces, colocar momentáneamente en suspenso toda su rica indagación en la cultura popular chilena, interesarse en los seres incorpóreos, de los simulacros y las simulaciones, y dejar para más adelante, en los años noventa, volver a Chile a fin de recuperar su programa en torno a la identidad chilena. Es destacable que el epílogo del libro inicie haciendo referencia a los imaginarios de infancia de Ruiz, los que a través de relatos familiares, ligados a su abuelo chilote y a su madre, construyeron una primera imagen de ese país en el que le tocó nacer. Luego serían sus lecturas las que configuren un mundo más complejo donde la poesía popular pero también la literatura de otras latitudes y tradiciones alimente sus ensoñaciones. Más tarde sus propias imágenes vendrían a desafiar los relatos oficiales y a sumarse a las historias posibles que esas tradiciones populares y cultas habían instalado en un inicio. Este libro recoge esas cartas lanzadas hace siglos para seguir conversando con Ruiz o su fantasma, donde quieran que estén, y afortunadamente también con todes nosotres. 